\title{
SURGICAL TREATMENT FOR LUMBAR DISK HERNIATION IN AN ADOLESCENT PATIENT: CLINICAL CASE STUDY
}

Received 12 July 2020;

Received in revised form 26 August 2020; Accepted 28 August 2020

\section{Lyubov Gornaeva (D), Galina Rumyantseva (i)}

Tver State Medical University, Tver, Russia

gornaeva-ns@rambler.ru

ABSTRACT - Osteochondrosis of the spine refers to one of the leading problems of modern medicine. This disease is most characteristic of patients aged 25 to 55 years. It is noted that adolescents are increasingly suffering from osteochondrosis of the spine and its complications in the form of a hernia of an intervertebral disc. The purpose of this report: to analyze the clinical picture and the results of surgical treatment of a rare clinical case in childhood, represented by a hernia of the lumbar intervertebral disc with radicular syndrome. Surgical treatment consisted of a combination of microdiscectomy and foraminotomy under the control of endoscopic techniques.

KEY W ORDS - osteochondrosis, herniation of an intervertebral disc, microdisectomy, foraminotomy.

\section{INTRODUCTION}

According to the data of the neurosurgical service of the Russian Federation, about 50 thousand patients per year are operated on for a hernia of an intervertebral disc. Among them, $0.5-2 \%$ patients tend to be adolescents under 18 years of age. The article presents a clinical case of successful surgical treatment for a hernia of an intervertebral disc in a 15 -year-old adolescent [1-4].

\section{CASE DESCRIPTION}

Patient M., 15 years old. Growth and development took place in accordance with gender and age.

Medical history. Back pain started 6 months prior to the first examination. Conservative treatment produced no effect. On admission the MRI of the lumbosacral region showed a paramedian right-sided hernia of the L4-L5 intervertebral disc up to $10 \mathrm{~mm}$ with stenosis of the intervertebral foramen on the right and compression on the nerve root.

On examination: complaints of pain in the lumbar region with radiation to the right lower limb, gait disturbance, numbness of the right lower limb. In neurological status, hypoesthesia was noted in the right lower leg, paresis of the right foot up to 3 points, tingling of the right leg when walking. Weight -57 $\mathrm{kg}$. Height $-164 \mathrm{~cm}$.

In a preoperative examination, weak myopia, mitral valve prolapse of the I-II degree, and vegetative symptoms were diagnosed.

A microsurgical operation was performed as follows: microdisectomy L4-L5, foraminotomy, radiculolysis $\mathrm{L} 5$ on the right with video endoscopic assistance.

Progress of the operation. A linear incision was made in the lumbar region in the projection L4-L5 $\sim 3.5 \mathrm{~cm}$ with installation of operating microscope. Radiculolysis of the root $\mathrm{L} 5$ was performed. The posterior longitudinal ligament above the herniation of the intervertebral disc was dissected, the latter was removed. The procedure was controlled by of a 30-degree endoscope, Foraminotomy and decompression of nerve structures were performed in the projection of the $\mathrm{L} 5$ root.

The postoperative period. Pain syndrome regressed on the first day. The child was vertical on the second day.

Histological examination of a removed hernia of the intervertebral disc revealed signs of connective tissue dysplasia in the form of extracellular matrix disorganization sites.

At discharge (on the $4^{\text {th }}$ day) the patient was at a satisfactory condition, had no complaints; movements and sensitivity in the right lower limb were recovered.

The teenager was discharged with a diagnosis of "Juvenile osteochondrosis: right-sided paramedian hernia of the L4-L5 intervertebral disc with stenosis of the foraminal opening, persistent lumbar ischialgia on the right."

At the follow-up examination after 3 months no complaints and neurological deficit were observed.

MRI control of the lumbar spine noted no signs of compression of the structures of the spinal cord; spinal canal, foraminal openings was not narrowed.

\section{DISCUSSION}

Currently, spinal osteochondrosis in children is considered as one of the common forms of chronic systemic damage to connective tissue [5-8]. Surgical intervention in the form of microdiscectomy in 
combination with foraminotomy under the control of endoscopic technique helped to achieve a good treatment effect in this clinical case. In the expanded foraminal opening, a reserve space is created for the nerve root, which reduces the risk of adhesions in the postoperative period, which can manifest as radicular pain [9].

\section{FUND | N G}

The reported study was funded by RFBR, project number No. 19-315-90124/19.

\section{REFERENCES}

1. Xie L, WU WJ, Liang Y. Comparison between Minimally Invasive Transforaminal Lumbar Interbody Fusion and Conventional Open Transforaminal Interbody Fusion: An Updated Metaanalysis. Chinese Medical Journal. 2016; 129: 1969-1986. https://doi. org/10.4103/0366-6999.187847

2. Konovalov NA, Nazarenko AG, Asyutin DS, ZeLENKov PV, ONOPRIENKo RA. Modern methods of treatment of degenerative disease of the intervertebral disk. Literature review. Voprosy neirokhirurgii im. N.N. Burdenko. 2016; 80 (4): 102-108. (In Russ). https // doi.org / 10.17116 / neiro2016804102-108

3. Sharif S, Afsar A. Learning Curve and Minimally Invasive Spine Surgery. World Neurosugery. 2018; 119: 472-478. https://doi.org/10.1016/j.wneu.2018.06.094

4. Bogduc N. Functional anatomy of the spine. Handbook of Clinical Neurology. 2016; 136: 675-688. https://doi.org/10.1016/B978-0-444-53486-6.00032-6

5. Bryant J, Mohan R, KoOtTappillil B, Wong K, YI PH. Minimally Invasive Spine Surgery: Analyzing Internet-based Education Material. Clinical Spine Surgery. 2018; 31 (3): E166-E170.

6. Kreinest M, Rillig J, Grutzner PA, Kuffer M, Tinelli M, MatschKe $S$. Analysis of complications and perioperative data after open or percutaneous dorsal instrumentation following traumatic spinal fracture of the thoracic and lumbar spine: a retrospective cohort study including 491 patients. European Spine Journal. 2017; 26 (5): 1535-1540. https://doi. org/10.1007/s00586-016-4911-8

7. Pak LM, Fogel Ha, Chaudhary Ma, Kwon NK, Barton LB, Koehlmoos T, Haider AH, SCHOENFELd AJ / Outpatient Spine Clinic Utilization is Associated with Redbced Emergency Department Visits Following Spine Surgery. Spine 2018; 43 (14): E836-E841. https://doi.org/10.1097/ BRS.0000000000002529

8. Grabel ZJ, Hart Ra, Clark AJ, Park SH, ShafFREY CI, SHEER JK, SMith JS. Adult Spinal Deformity Knowledge in Orthopedic Spine Surgeons: Impact of Fellowship Training, Experience, and Practice Characteristics. Spine Derformity 2018; 6 (1): 60-66. https://doi.org/10.1016/j.jspd.2017.06.003
9. Fehlings MG, Tetreault L, Nater A, Choma T, Harrop J, Mroz T, Santaguida C, Smith JS. The Aging of the Global Population: The Changing Epidemiology of Disease and Spinal Disorders. Neurosurgery. 2015; 77 (Suppl 4): S1-S5. https://doi. org/10.1227/NEU.0000000000000953 